\title{
Genetic parameters for buffalo milk yield and milk quality traits using Bayesian inference
}

\author{
R. R. Aspilcueta-Borquis, ${ }^{*}$ F. R. Araujo Neto, ${ }^{*}$ F. Baldi, ${ }^{*}$ A. B. Bignardi, ${ }^{*}$ L. G. Albuquerque, ${ }^{*} \dagger$ \\ and $\mathrm{H}$. Tonhati ${ }^{*} \dagger^{1}$ \\ *Department of Animal Science, São Paulo State University (FCAV/UNESP), Jaboticabal, SP, 14884 900, Brazil \\ †Conselho Nacional de Desenvolvimento Científico e Tecnologico (CNPq) and Instituto Nacional de Ciência e Tecnologia - Ciência Animal \\ (INCT- CA), Viçosa, MG, 36570 000, Brazil
}

\begin{abstract}
The availability of accurate genetic parameters for important economic traits in milking buffaloes is critical for implementation of a genetic evaluation program. In the present study, heritabilities and genetic correlations for fat (FY305), protein (PY305), and milk (MY305) yields, milk fat $(\% \mathrm{~F})$ and protein $(\% \mathrm{P})$ percentages, and SCS were estimated using Bayesian methodology. A total of 4,907 lactations from 1,985 cows were used. The (co)variance components were estimated using multiple-trait analysis by Bayesian inference method, applying an animal model, through Gibbs sampling. The model included the fixed effects of contemporary groups (herd-year and calving season), number of milking (2 levels), and age of cow at calving as (co)variable (quadratic and linear effect). The additive genetic, permanent environmental, and residual effects were included as random effects in the model. The posterior means of heritability distributions for MY305, FY305, PY305, \%F, P\%, and SCS were 0.22, 0.21, 0.23, 0.33, 0.39 , and 0.26 , respectively. The genetic correlation estimates ranged from -0.13 (between $\% \mathrm{P}$ and SCS) to 0.94 (between MY305 and PY305). The permanent environmental correlation estimates ranged from -0.38 (between MY305 and \%P) to 0.97 (between MY305 and PY305). Residual and phenotypic correlation estimates ranged from -0.26 (between PY305 and SCS) to 0.97 (between MY305 and PY305) and from -0.26 (between MY305 and SCS) to 0.97 (between MY305 and PY305), respectively. Milk yield, milk components, and milk somatic cells counts have enough genetic variation for selection purposes. The genetic correlation estimates suggest that milk components and milk somatic cell counts would be only slightly affected if increasing milk yield were the selection goal. Selecting to increase FY305 or PY305 will also increase MY305, $\% \mathrm{P}$, and $\% \mathrm{~F}$.
\end{abstract}

Received August 6, 2009.

Accepted January 23, 2010.

${ }^{1}$ Corresponding author: tonhati@fcav.unesp.br
Key words: Gibbs sampling, milk composition, milking buffalo

\section{INTRODUCTION}

According to FAO (2006), there are about 174 million head of buffalo worldwide, being mainly concentrated in India (8 million head). One of the largest buffalo populations in the world is the Brazilian buffalo with 1.2 million head. In the last decades, the Brazilian buffalo's milk yield per lactation has significantly increased from $717.3 \mathrm{~kg}$ in 1995 (Tonhati et al., 1996) to 1,650.0 $\mathrm{kg}$ in recent years (Ramos et al., 2006; Tonhati et al., 2008). This is mainly a consequence of improvement in management, infrastructure, and feeding practices on buffalo farms (Malhado et al., 2007). However, to develop a buffalo breeding program it is necessary to implement systematic milk recording to collect phenotypic and pedigree data (Seno et al., 2007).

Buffalo milk is characterized by a high percentage of fat and protein, which could be used to increase milk's added value, following the current tendency of the worldwide milk markets. In the process of cheese making, fat and casein are the major milk solids incorporated into the final product; thus, these milk components are routinely used in many countries as a criterion to determine the milk price. In Western countries, most buffalo milk production is transformed to buffalo Mozzarella cheese, an expensive fresh cheese, and some industries are paying for milk quality.

Somatic cell count is a good indicator of milk quality and cow health; high SCC are associated with a reduction in milk yield and an increase in the incidence of subclinical mastitis in sheep (Othmane et al., 2002) and cattle (Castillo-Juarez et al., 2002). In milking buffalo, Cerón-Muñoz et al. (2002) reported that high levels of SCC cause reductions in lactose, fat, casein, calcium, and potassium in milk and thus reduce the quantity and quality of cheese produced.

The improvement through selection of traits associated with milk quality and milk yield for milking buf- 
Table 1. Summary of data structure and descriptive statistics for fat (FY305), protein (PY305), and milk (MY305) yields, milk fat $(\% \mathrm{~F})$ and protein $(\% \mathrm{P})$ percentages, and SCS

\begin{tabular}{lcccrrr}
\hline Description & $\begin{array}{c}\text { MY305 } \\
(\mathrm{kg})\end{array}$ & $\begin{array}{c}\text { FY305 } \\
(\mathrm{kg})\end{array}$ & $\begin{array}{c}\text { PY305 } \\
(\mathrm{kg})\end{array}$ & $\% \mathrm{~F}$ & $\% \mathrm{P}$ & SCS \\
\hline Number of records & 4,905 & 1,220 & 1,220 & 1,220 & 1,220 & 1,220 \\
Sires & 140 & 103 & 103 & 103 & 103 & 103 \\
Cows & 1,986 & 572 & 572 & 572 & 572 & 572 \\
Mean & 1,814 & 119.26 & 77.38 & 6.84 & 4.27 & 5.02 \\
SD & 641.08 & 37.40 & 24.26 & 1.35 & 0.54 & 1.26 \\
CV $(\%)$ & 38.4 & 32.6 & 30.4 & 19.1 & 11.2 & 24.6 \\
Number of $\mathrm{CG}^{1}$ & 197 & 49 & 49 & 49 & 49 & 49 \\
\hline
\end{tabular}

${ }^{1}$ Contemporary groups.

faloes is dependent on the availability of reliable genetic parameter estimates for these traits. The accuracy of genetic parameter estimates is determined by many factors, such as the quantity and quality of information (records and pedigree), the statistical model applied, and the method of covariance estimation. The implementation of a multiple-trait model allows the incorporation of all information available from an animal and, hence, increasing the accuracy of genetic parameter estimates (Pollak et al., 1983).

The REML and Bayesian methods have been applied extensively in animal breeding to estimate covariance components and genetic parameters. The Bayes methodology provides a solution for the finite sample size problem, because an exact a posteriori distribution exists for each large or small data set from which inferences can be drawn. When a large data set is analyzed, a priori information tends to be subjugated by the likelihood function in the establishment of the a posteriori distribution. In this case, the parameter estimates are close to those obtained by frequentist methods based in likelihood functions. However, this may not be true when the sample size is limited because the maximum likelihood procedure only presents well-defined properties when the sample size is large enough (Gianola and Fernando, 1986).

There are few papers reporting genetic parameter estimates in buffalo milk yield (Rosati and Van Vleck, 2002; Hurtado-Lugo et al., 2006; Tonhati et al., 2008) and milk components (Tonhati et al., 2000; Rosati and Van Vleck, 2002). To date, there are no studies reporting estimation of SCS genetic parameters in buffalo.

The objective of the present study was to estimate heritability and correlations for milk, fat, and protein yields, SCS, and fat and protein percentages in buffaloes using Bayesian methodology.

\section{MATERIALS AND METHODS}

Milk yield records of Murrah buffaloes were obtained from monthly test-days from 1985 to 2008 belonging to 12 herds located in São Paulo state, Brazil. Animals were raised on pasture with feed supplementation during the dry period from April to September. A total of 4,907 lactations from 1,985 cows were analyzed.

The studied traits were accumulated 305-d fat (FY305), protein (PY305), and milk (MY305) yields, milk fat $(\mathbf{\%} \mathbf{F})$ and protein $(\mathbf{\%} \mathbf{P})$ percentages, and SCS. According to Tonhati et al. (2000), the $\% \mathrm{~F}, \% \mathrm{P}$, and SCC values were obtained by averaging the monthly test-day records per lactation. The average lactation SCC was transformed to a logarithmic scale, using the following equation: SCS $=\left[\log _{2}(\mathrm{SCC} / 100.000)\right]+3$, described by Dabdoub and Shook (1984).

The lactation records were unadjusted for days in milk, and lactation records with a length $>305 \mathrm{~d}$ were truncated at this point, as suggested by Tonhati et al. (2000). Lactation records $<90 \mathrm{~d}$ of lactation were deleted. It was considered that the first test-day milk record was measured from d 5 to 75 day after calving. The age of cows varied from 2 to 8 yr.

The contemporary group (CG) was defined as animals that calved in the same herd, year, and season (season $=1$ from April to September and season = 2 from October to March). Contemporary groups with fewer than 5 lactations (animals) and animals with records for each trait above or below 3.0 standard deviation from CG average were deleted from the analyses. There were 11,632 animals in the relationship matrix and all generations back were utilized. The data structure is presented in Table 1.

The (co)variance components were estimated by Bayesian inference in multi-trait analyses with the GIBBS2F90 software (Misztal, 2007). The model of analysis included fixed effects of CG, number of milking (1 or 2), and the covariable cow age at calving (linear and quadratic effects). Additive genetic and permanent environmental effects were included as random effects. The model adopted, represented in matrix notation, was

$$
\mathbf{y}=\mathbf{X} \boldsymbol{\beta}+\mathbf{Z a}+\mathbf{W} \mathbf{p}+\mathbf{e}
$$


where $\mathbf{y}$ is a vector of observed traits; $\mathbf{X}$ is the incidence matrix of fixed effects; $\boldsymbol{\beta}$ is a vector of fixed effects $(\mathrm{CG}$, number of milking, and the covariable cow age at calving as linear and quadratic effects); $\mathbf{Z}$ is the incidence matrix of additive genetic random effects; $\mathbf{a}$ is a vector of additive genetic random effects; $\mathbf{W}$ is the incidence matrix of permanent environmental random effect; $\mathbf{p}$ is a vector of permanent environmental random effects; and $\mathbf{e}$ is a vector of random error effects.

Uniform a priori distribution was defined for fixed effects $(\boldsymbol{\beta})$. Gaussian and inverted Wishart distributions were defined as a priori distributions for random effects and (co)variance components, respectively.

$$
\begin{gathered}
\boldsymbol{\beta} \propto \text { constant; } \\
a \mid \mathbf{G} \sim M V N[0,(\mathbf{G} \otimes \mathbf{A})] ; \\
p \mid \mathbf{P} \sim M V N\left[0,\left(\mathbf{P} \otimes \mathbf{I}_{\mathbf{n}}\right)\right] ; \\
\mathbf{G} \mid S_{g}, v_{g} \sim I W\left[S_{g} v_{g}, v_{g}\right] ; \\
\mathbf{P} \mid S_{p}, v_{p} \sim I W\left[S_{p} v_{p}, v_{p}\right] ; \\
\mathbf{R} \mid S_{r}, v_{r} \sim I W\left[S_{r} v_{r}, v_{r}\right] ;
\end{gathered}
$$

where $\mathbf{A}, \mathbf{G}, \mathbf{P}, \mathbf{R}$, and $\mathbf{I}_{\mathbf{n}}$ are the matrices of relationship, (co)variances of additive genetic effects, permanent environmental effects, residual, and identity, respectively; $\otimes$ is the Kronecker product; and $S_{g}$ and $v_{g} ; S_{p}$ and $v_{p} ; S_{r}$ and $v_{r}$ are the values of a priori and degree of freedom for additive genetic, permanent environmental, and residual (co)variances, respectively. Genetic covariance estimates reported in the literature were used as a priori values in the analyses (CastilloJuarez et al., 2002).

A total of 2.0 million samples were generated in the analyses and a burn-in period of 200,000 samples was used with samples taken each 50 cycles. The convergence was verified through graphical inspection (traceplots) and also using the Gibbanal program (Van Kaam, 1997).

The descriptive statistics (mean, median, mode, and standard deviation) of posterior distribution for each parameter were obtained from effective samples. The highest posterior density (HPD) region or confidence interval provides the interval that includes $95 \%$ of samples and is a measure of reliability. Also, the HPD can be applied to nonsymmetric distributions (Hyndman, 1996).

\section{RESULTS AND DISCUSSION}

After verifying the graphics and the results obtained by Gibbanal program (results not shown), the burn-in period considered was sufficient to reach convergence in all parameter estimates. The number of effective samples varied from 350 to 35,996 and was sufficient to obtain measures of central tendency and the HPD region for each parameter. As the complexity of the model increased, the number of effective samples decreased.

The number of samples discarded in the burn-in period and the serial correlation obtained between samples in the Markov chain are main aspects in Bayesian analyses (Resende et al., 2001). In general, as the number of parameters to be estimated in the model increases, the length of the burn-in period and the serial correlation will also increase, reducing the number of effective samples.

The mean, median, and mode were similar for most of the parameter estimates (Tables 2, 3, 4, 5, and 6), indicating that the posterior distribution of the parameter estimates is close to normal distribution. Nevertheless, genetic correlation estimates showed different results, and nonsymmetric distributions were obtained. Genetic correlation estimates showed high standard deviations and large HPD regions.

Heritability estimates for MY305 (Table 2) were moderate (0.216), suggesting that MY305 has enough additive genetic variation to respond to selection. Similar results were reported by Tonhati et al. (2000) and Tonhati et al. (2008) using REML. Hurtado-Lugo et al. (2006), working with Colombian milking buffaloes, obtained a heritability estimate for MY305 close to that reported in the present study by applying a test-day model of finite dimension. However, Rosati and Van Vleck (2002) in Italy and using REML, reported lower heritability estimate for MY305 (0.14) than the value obtained in the present study.

The heritability estimates obtained for FY305 and PY305 (Table 2) and for \%F and \%P (Table 3) were moderate. Rosati and Van Vleck (2002), working with Italian buffaloes and applying the REML method, reported lower heritability estimates for FY305, PY305, $\% \mathrm{~F}$, and $\% \mathrm{P}$, with values of $0.11,0.14,0.14$ and 0.10 , respectively. In Brazil, Tonhati et al. (2000), working with the same set of data but with fewer lactation records and applying REML, obtained heritability estimates for $\% \mathrm{~F}(0.21)$ and $\% \mathrm{P}(0.26)$ similar to those reported in the present study. Differences in environmental conditions and management between Brazil and Italy may explain the difference between results from the two countries. 
Table 2. Posterior means and highest posterior density (HDP) region of variance components and genetic parameters for milk yield accumulated for 305-d milk (MY305), fat (FY305), and protein (PY305) yields

\begin{tabular}{|c|c|c|c|c|c|}
\hline \multirow[b]{2}{*}{ Trait } & \multirow[b]{2}{*}{ Parameter $^{1}$} & \multirow[b]{2}{*}{ Mean } & \multirow[b]{2}{*}{$\mathrm{SD}^{2}$} & \multicolumn{2}{|c|}{ HPD } \\
\hline & & & & Low limit & High limit \\
\hline \multirow[t]{5}{*}{ MY305 } & $\sigma_{a}^{2}$ & 49,534 & $8,123.509$ & 33,750 & 64,860 \\
\hline & $\sigma_{c}^{2}$ & 52,903 & $6,346.316$ & 40,480 & 65,570 \\
\hline & $\sigma_{r}^{2}$ & 126,898 & $3,355.894$ & 120,100 & 133,200 \\
\hline & $\sigma_{p}^{2}$ & 229,136 & $6,240.853$ & 217,540 & 241,650 \\
\hline & $\begin{array}{l}\mathrm{h}^{2} \\
\mathrm{c}^{2}\end{array}$ & $\begin{array}{l}0.216 \\
0.231\end{array}$ & $\begin{array}{l}0.031 \\
0.028\end{array}$ & $\begin{array}{l}0.155 \\
0.177\end{array}$ & $\begin{array}{l}0.278 \\
0.285\end{array}$ \\
\hline \multirow[t]{5}{*}{ FY305 } & $\sigma_{a}^{2}$ & 242 & 63.130 & 124.000 & 365.500 \\
\hline & $\sigma_{c}^{2}$ & 247 & 48.759 & 150.300 & 349.700 \\
\hline & $\sigma_{r}^{2}$ & 669 & 27.022 & 617.1 & 721.800 \\
\hline & $\sigma_{p}^{2}$ & 1,161 & 46.235 & $1,072.440$ & $1,249.900$ \\
\hline & $\begin{array}{l}\mathrm{h}^{2} \\
\mathrm{c}^{2}\end{array}$ & $\begin{array}{l}0.208 \\
0.216\end{array}$ & $\begin{array}{l}0.050 \\
0.044\end{array}$ & $\begin{array}{l}0.111 \\
0.128\end{array}$ & $\begin{array}{l}0.301 \\
0.299\end{array}$ \\
\hline \multirow[t]{5}{*}{ PY305 } & $\sigma_{a}^{2}$ & 97 & 16.414 & 66.070 & 130.500 \\
\hline & $\sigma_{c}^{2}$ & 80 & 13.188 & 55.610 & 106.200 \\
\hline & $\sigma_{r}^{2}$ & 245 & 8.091 & 229.400 & 261.200 \\
\hline & $\sigma_{p}^{2}$ & 422.849 & 13.715 & 397.580 & 450.130 \\
\hline & $\begin{array}{l}\mathrm{h}^{2} \\
\mathrm{c}^{2}\end{array}$ & $\begin{array}{l}0.229 \\
0.192\end{array}$ & $\begin{array}{l}0.035 \\
0.029\end{array}$ & $\begin{array}{l}0.159 \\
0.130\end{array}$ & $\begin{array}{l}0.301 \\
0.249\end{array}$ \\
\hline
\end{tabular}

The heritability estimate for SCS obtained in the present study was 0.255 , indicating that this trait could probably respond to selection. In general for dairy cattle, and applying different models and methods to transform SCC records, heritability estimates reported in the literature for SCS ranged from 0.07 to 0.23 (Da et al., 1992; Weller et al., 1992; Koivula et al., 2005). El-Saied et al. (1998) and Hamann et al. (2004), working with milking sheep, reported heritability estimates for SCS that varied from 0.06 to 0.16 . The SCS heritability estimate obtained was similar to those reported in the literature. Nevertheless, it is difficult to compare the results obtained in the present work with studies in the literature, because other livestock species with different milk production levels and methods to transform the SCC records were used. The estimates of variance of permanent environmental effect as a proportion of total variance were moderate and similar to heritability estimates with the exception of \%P and SCS, but the permanent environmental effect had less influence on these traits than did the additive genetic effect.

The genetic correlation estimates between traits are presented in Table 4. The genetic correlation estimates obtained among MY305, FY305, and PY305 were high and close to those reported by Rosati and Van Vleck (2002). Genetic correlation estimates close to zero were obtained between MY305 and \%F and between MY305 and $\% \mathrm{P}$, with values of -0.04 and -0.07 , respectively. Tonhati et al. (2000) and Rosati and Van Vleck (2002) also obtained negative and low genetic correlation estimates of -0.18 and -0.08 between MY305 and $\% \mathrm{~F}$, respectively, and of -0.23 and -0.12 between MY305 and \% $\mathrm{P}$, respectively. De Paula et al. (2008) reported the same trend for the genetic correlations between milk yield and milk components in dairy cattle. In the present study, a small increase in milk yield would slightly affect the fat and protein percentages because the level of milk production was low compared with that in dairy cattle.

The genetic correlation estimates between MY305 and SCS were close to zero $(-0.06)$. In dairy cattle, positive genetic correlation estimates, around 0.20 , between MY305 and SCS were reported by Welper and Freeman (1992), Rupp and Boichard (1999), and Carlén et al. (2004). In the present study, the genetic correlation obtained between MY305 and SCS was close to the values reported for milking sheep, varying from -0.08 to -0.16 (El-Saied et al., 1998; Hamann et al., 2004). 
Table 3. Posterior means and highest posterior density (HPD) region of variance components and genetic parameters for milk fat percentage $(\mathrm{F} \%)$, milk protein percentage $(\% \mathrm{P})$, and SCS

\begin{tabular}{llllcc}
\hline & & & & \multicolumn{2}{c}{ HPD } \\
\cline { 5 - 6 } Trait & Parameter $^{1}$ & Mean & $\mathrm{SD}^{2}$ & Low limit & High limit \\
\hline$\% \mathrm{~F}$ & $\sigma_{a}^{2}$ & 0.261 & 0.064 & 0.133 & 0.379 \\
& $\sigma_{c}^{2}$ & 0.240 & 0.052 & 0.135 & 0.337 \\
& $\sigma_{r}^{2}$ & 0.295 & 0.018 & 0.258 & 0.329 \\
& $\sigma_{p}^{2}$ & 0.791 & 0.045 & 0.699 & 0.873 \\
& $\mathrm{~h}^{2}$ & 0.327 & 0.072 & 0.185 & 0.459 \\
& $\mathrm{c}^{2}$ & 0.298 & 0.066 & 0.169 & 0.426 \\
& $\sigma_{a}^{2}$ & 0.033 & 0.008 & 0.018 & 0.048 \\
& $\sigma_{c}^{2}$ & 0.020 & 0.006 & 0.008 & 0.031 \\
& $\sigma_{r}^{2}$ & 0.029 & 0.002 & 0.025 & 0.032 \\
& $\sigma_{p}^{2}$ & 0.081 & 0.005 & 0.072 & 0.091 \\
& $\mathrm{~h}^{2}$ & 0.392 & 0.083 & 0.232 & 0.558 \\
& $\mathrm{c}^{2}$ & 0.250 & 0.078 & 0.100 & 0.399 \\
& $\sigma_{a}^{2}$ & 0.403 & 0.106 & 0.199 & 0.603 \\
& $\sigma_{c}^{2}$ & 0.318 & 0.086 & 0.155 & 0.485 \\
& $\sigma_{r}^{2}$ & 0.855 & 0.051 & 0.753 & 0.954 \\
& $\sigma_{p}^{2}$ & 1.578 & 0.082 & 1.428 & 1.750 \\
& $\mathrm{~h}^{2}$ & 0.255 & 0.058 & 0.134 & 0.364 \\
& $\mathrm{c}^{2}$ & 0.199 & 0.053 & 0.098 & 0.305 \\
\hline
\end{tabular}

${ }^{1} \sigma_{a}^{2}=$ additive genetic variance estimates; $\sigma_{c}^{2}=$ permanent environmental variance estimates; $\sigma_{r}^{2}=$ residual variance estimates; $\sigma_{p}^{2}=$ phenotypic variance estimates; $\mathrm{h}^{2}=$ heritability estimates; $\mathrm{c}^{2}=$ permanent environmental variance estimates as proportions of phenotypic variance estimates.

${ }^{2}$ Posterior SD.

Table 4. Posterior means and highest posterior density (HPD) region of genetic correlation estimates between traits

\begin{tabular}{|c|c|c|c|c|}
\hline \multirow[b]{2}{*}{ Trait $^{1}$} & \multirow[b]{2}{*}{ Mean } & \multirow[b]{2}{*}{ SD } & \multicolumn{2}{|c|}{$\mathrm{HPD}$} \\
\hline & & & Low limit & High limit \\
\hline MY305/FY305 & 0.753 & 0.071 & 0.616 & 0.881 \\
\hline MY305/PY305 & 0.942 & 0.018 & 0.907 & 0.974 \\
\hline MY305/\%F & -0.038 & 0.186 & -0.420 & 0.310 \\
\hline MY305/\%P & -0.072 & 0.173 & -0.431 & 0.290 \\
\hline MY305/SCS & -0.062 & 0.199 & -0.435 & 0.308 \\
\hline FY305/PY305 & 0.799 & 0.059 & 0.681 & 0.903 \\
\hline FY305/\%F & 0.613 & 0.122 & 0.370 & 0.817 \\
\hline FY305/\%P & 0.213 & 0.190 & -0.173 & 0.592 \\
\hline FY305/SCS & -0.020 & 0.205 & -0.423 & 0.377 \\
\hline PY $305 / \% \mathrm{~F}$ & 0.106 & 0.167 & -0.240 & 0.446 \\
\hline PY305/\%P & 0.262 & 0.164 & -0.073 & 0.571 \\
\hline PY305/SCS & -0.104 & 0.181 & -0.454 & 0.243 \\
\hline$\% \mathrm{~F} / \% \mathrm{P}$ & 0.442 & 0.149 & 0.138 & 0.731 \\
\hline$\% \mathrm{~F} / \mathrm{SCS}$ & -0.055 & 0.204 & -0.427 & 0.343 \\
\hline$\% \mathrm{P} / \mathrm{SCS}$ & -0.126 & 0.201 & -0.5294 & 0.246 \\
\hline
\end{tabular}

${ }^{1} \mathrm{MY} 305=305-\mathrm{d}$ milk yield; FY305 $=305$-d fat yield; PY305 $=305-\mathrm{d}$ protein yield; $\% \mathrm{~F}=$ milk fat percentage; $\% \mathrm{P}=$ milk protein percentage.
Table 5. Posterior means and highest posterior density (HPD) region of permanent environment correlation estimates between traits

\begin{tabular}{|c|c|c|c|c|}
\hline \multirow[b]{2}{*}{ Trait $^{1}$} & \multirow[b]{2}{*}{ Mean } & \multirow[b]{2}{*}{$\mathrm{SD}$} & \multicolumn{2}{|c|}{ HPD } \\
\hline & & & Low limit & High limit \\
\hline MY305/FY305 & 0.860 & 0.044 & 0.773 & 0.941 \\
\hline MY305/PY305 & 0.968 & 0.013 & 0.940 & 0.990 \\
\hline MY305/\%F & -0.224 & 0.161 & -0.550 & 0.080 \\
\hline MY305/\%P & -0.381 & 0.191 & -0.758 & -0.046 \\
\hline MY305/SCS & -0.199 & 0.174 & -0.534 & 0.138 \\
\hline FY305/PY305 & 0.862 & 0.043 & 0.777 & 0.940 \\
\hline FY305/\%F & 0.264 & 0.156 & -0.061 & 0.544 \\
\hline FY305/\%P & -0.267 & 0.212 & -0.698 & 0.161 \\
\hline FY305/SCS & -0.230 & 0.182 & -0.597 & 0.120 \\
\hline PY305/\%F & -0.169 & 0.176 & -0.518 & 0.169 \\
\hline PY305/\%P & -0.156 & 0.216 & -0.588 & 0.257 \\
\hline PY305/SCS & -0.160 & 0.183 & -0.518 & 0.183 \\
\hline$\% \mathrm{~F} / \% \mathrm{P}$ & 0.263 & 0.181 & -0.106 & 0.616 \\
\hline$\% \mathrm{~F} / \mathrm{SCS}$ & 0.021 & 0.201 & -0.362 & 0.424 \\
\hline$\% \mathrm{P} / \mathrm{SCS}$ & 0.253 & 0.233 & -0.195 & 0.733 \\
\hline
\end{tabular}

${ }^{1}$ MY305 = 305-d milk yield; FY305 = 305-d fat yield; PY305 $=305-\mathrm{d}$ protein yield; $\% \mathrm{~F}=$ milk fat percentage; $\% \mathrm{P}=$ milk protein percentage.

Given the correlation values, there may be an opportunity to include PY305 or FY305 as a selection criterion to simultaneously increase milk yield and components, because PY305 and FY305 are favorably correlated with MY305, \%P, and \%F. Similar results were reported by Rosati and Van Vleck (2002). The genetic correlation estimate between $\% \mathrm{~F}$ and $\% \mathrm{P}$ was 0.44 , suggesting that selection for higher $\% \mathrm{P}$ in milk would also increase $\% \mathrm{~F}$. In addition, a similar genetic correlation estimate between $\% \mathrm{~F}$ and $\% \mathrm{P}$ was reported by Tonhati et al. (2000). However, Rosati and Van Vleck (2002) obtained a higher genetic correlation es-

Table 6. Posterior means and highest posterior density (HPD) region of residual correlation estimates between traits

\begin{tabular}{|c|c|c|c|c|}
\hline \multirow[b]{2}{*}{ Trait $^{1}$} & \multirow[b]{2}{*}{ Mean } & \multirow[b]{2}{*}{ SD } & \multicolumn{2}{|c|}{ HPD } \\
\hline & & & Low limit & High limit \\
\hline MY305/FY305 & 0.930 & 0.005 & 0.920 & 0.940 \\
\hline MY305/PY305 & 0.971 & 0.002 & 0.967 & 0.975 \\
\hline MY305/\%F & -0.046 & 0.047 & -0.130 & 0.050 \\
\hline MY305/\%P & -0.063 & 0.047 & -0.153 & 0.030 \\
\hline MY305/SCS & -0.264 & 0.041 & -0.345 & -0.184 \\
\hline FY305/PY305 & 0.919 & 0.006 & 0.908 & 0.930 \\
\hline FY305 $/ \% \mathrm{~F}$ & 0.282 & 0.041 & 0.200 & 0.360 \\
\hline FY305/\%P & 0.014 & 0.046 & -0.080 & 0.104 \\
\hline FY305/SCS & -0.202 & 0.041 & -0.281 & -0.120 \\
\hline PY305 $/ \% \mathrm{~F}$ & -0.015 & 0.046 & -0.107 & 0.073 \\
\hline PY305/\%P & 0.139 & 0.045 & 0.049 & 0.226 \\
\hline PY305/SCS & -0.256 & 0.041 & -0.335 & -0.175 \\
\hline$\% \mathrm{~F} / \% \mathrm{P}$ & 0.215 & 0.042 & 0.133 & 0.297 \\
\hline$\% \mathrm{~F} / \mathrm{SCS}$ & 0.160 & 0.042 & 0.077 & 0.241 \\
\hline$\% \mathrm{P} / \mathrm{SCS}$ & 0.048 & 0.044 & -0.039 & 0.131 \\
\hline
\end{tabular}

${ }^{1} \mathrm{MY} 305=305-\mathrm{d}$ milk yield; FY305 $=305-\mathrm{d}$ fat yield; PY305 $=305-\mathrm{d}$ protein yield; $\% \mathrm{~F}=$ milk fat percentage; $\% \mathrm{P}=$ milk protein percentage. 
Table 7. Posterior means and highest posterior density (HPD) region of phenotypic correlation estimates between traits

\begin{tabular}{lrrrr}
\hline & & & \multicolumn{2}{c}{ HPD } \\
\cline { 4 - 5 } Trait $^{1}$ & Mean & SD & Low limit & High limit \\
\hline MY305/FY305 & 0.877 & 0.008 & 0.861 & 0.893 \\
MY305/PY305 & 0.962 & 0.002 & 0.958 & 0.967 \\
MY305/\%F & -0.088 & 0.040 & -0.160 & -0.01 \\
MY305/\%P & -0.143 & 0.040 & -0.220 & -0.063 \\
MY305/SCS & -0.200 & 0.038 & -0.276 & -0.128 \\
FY305/PY305 & 0.881 & 0.008 & 0.865 & 0.895 \\
FY305/\%F & 0.366 & 0.032 & 0.298 & 0.424 \\
FY305/\%P & 0.008 & 0.039 & -0.073 & 0.083 \\
FY305/SCS & -0.167 & 0.038 & -0.236 & -0.090 \\
PY305/\%F & -0.012 & 0.041 & -0.086 & 0.074 \\
PY305/\%P & 0.109 & 0.034 & 0.030 & 0.181 \\
PY305/SCS & -0.198 & 0.037 & -0.265 & -0.119 \\
\%F/\%P & 0.311 & 0.036 & 0.244 & 0.382 \\
\%F/SCS & 0.056 & 0.038 & -0.020 & 0.130 \\
\%P/SCS & 0.034 & 0.039 & -0.037 & 0.113 \\
\hline
\end{tabular}

${ }^{1} \mathrm{MY} 305=305$-d milk yield; FY305 = 305-d fat yield; PY305 = 305-d protein yield; $\% \mathrm{~F}=$ milk fat percentage; $\% \mathrm{P}=$ milk protein percentage.

timate than that reported in the present study. The genetic correlation estimates of $\% \mathrm{~F}$ and $\% \mathrm{P}$ with SCS were low and negative $(-0.06$ and -0.13 , respectively). These results suggest that selection to increase $\% \mathrm{P}$ or $\% \mathrm{~F}$ would not negatively affect SCS.

As expected, the phenotypic correlation estimates of MY305 with FY305 and PY305 were high and positive (Table 7). The phenotypic correlations of MY305 with $\% \mathrm{~F}$ and $\% \mathrm{P}$ were low and negative. Tonhati et al., (2000) reported higher phenotypic correlation estimates between these traits. The SCS showed some degree of antagonism with yield traits such as MY305, FY305, and PY305.

\section{CONCLUSIONS}

Milk yield, milk components, and milk SCC in Murrah buffaloes in Brazil have sufficient genetic variation for selection purposes. The results obtained in the present study suggest that selection to increase milk yield will only slightly affect milk composition and milk quality. However, because the correlation estimates obtained in the present paper showed large confidence intervals, further studies with larger data sets are recommended. Additionally, selection to increase FY305 or PY305 will also increase MY305, \% $\mathrm{P}$, and $\% \mathrm{~F}$.

\section{ACKNOWLEDGMENTS}

This study was supported by the State of São Paulo Research Foundation (Fapesp, São Paulo, SP, Brazil) and the National Council of Technological and Scientific Development (CNPq, Brasilia, DF, Brazil).

\section{REFERENCES}

Carlén, E., E. Strandberg, and A. Roth. 2004. Genetic parameters for clinical mastitis, somatic cell counts and production in the three first lactation of Swedish Holstein cows. J. Dairy Sci. 87:30623070.

Castillo-Juarez, H., P. A. Oltenacu, and E. G. Cienfuegos-Rivas. 2002. Genetic and phenotypic relationships among milk production and composition traits in primiparous Holstein cows in two different herd environments. Livest. Prod. Sci. 78:223-231.

Cerón-Muñoz, M., H. Tonhati, J. Duarte, J. Oliveira, M. MuñozBerrocal, and H. Jurado-Gámez. 2002. Factors affecting somatic cell counts and their relations with milk and milk constituent yield in buffaloes. J. Dairy Sci. 85:2885-2889.

Da, Y., M. Grossman, I. Misztal, and G. R. Wiggans. 1992. Estimation of genetic parameters for somatic cell score in Holsteins. J. Dairy Sci. $75: 2265-2271$.

Dabdoub, S. A. M., and G. E. Shook. 1984. Phenotypic relations among milk yield, somatic count cells, and mastitis. J. Dairy Sci. 67:163-164.

De Paula, M. C., E. N. Martins, L. O. C. Silva, L. Oliveira, A. A. Valotto, and E. Gasparino. 2008. Estimates of genetic parameters for yield and composition of milk of Holstein cows in Paraná State. Braz. J. Anim. Sci. 37:824-828.

El-Saied, U. M., J. A. Carriedo, L. F. De La Fuente, and F. San Primitivo. 1998. Genetic parameters of lactation cell counts and milk and protein yields in dairy ewes. J. Dairy Sci. 82:639-644.

FAO (Food and Agriculture Organization). 2006. http://faostat.fao. org. Accessed June 1, 2009.

Gianola, D., and R. L. Fernando. 1986. Bayesian methods in animal breeding theory. J. Anim. Sci. 63:217-244.

Hamann, H., A. Horstick, A. Wessels, and O. Distl. 2004. Estimation of genetic parameters for test day milk production, somatic cell score and litter size at birth in East Friesian ewes. Livest. Prod. Sci. $87: 153-160$.

Hurtado-Lugo, N., M. Cerón-Muñoz, and A. Guitérrez-Valencia. 2006. Estimates of genetic parameters of milk yield in test day analysis in buffaloes of the Colombian Atlantic Coast. Livest. Res. Rural Dev. 18:3. http://www.lrrd.org/lrrd18/3/hurt18039.htm Accessed Aug. 4, 2009.

Hyndman, R. J. 1996. Computing and graphing highest density regions. Am. Stat. 50:120-126.

Koivula, M., E. A. Mantysaari, E. Negussie, and T. Serenius. 2005. Genetic and phenotypic relationships among milk yield and somatic cell count before and after clinical mastitis. J. Dairy Sci. $88: 827-833$.

Malhado, C. H., A. Ramos, P. Carneiro, J. Souza, and A. Piccinin. 2007. Genetic and phenotypic parameters for milk production of Murrah buffaloes. Braz. J. Anim. Sci. 37:376-379.

Misztal, I. 2007. BLUPF90 family of programs. http://nce.ads.uga. edu/ ignacy/newprograms.html. Accessed March 12, 2009.

Othmane, M. H., J. A. Carriedo, F. San Primitivo, and L. F. De La Fuente. 2002. Genetic parameters for lactation traits of milking ewes: Protein content and composition, fat, somatic cells and individual laboratory cheese yield. Genet. Sel. Evol. 34:581-596.

Pollak, E. J., J. V. Werf, and R. L. Quaas. 1983. Selection bias and multiple trait evaluation. J. Dairy Sci. 67:1590-1595.

Ramos, A. A., C. H. Malhado, P. L. Carneiro, H. C. Gonçalves, and D. M. Azevedo. 2006. Phenotypic and genetic characterization of the milk yield and calving interval in buffalo of the Murrah breed. Braz. J. Agric. Res. 41:1261-1267.

Resende, M. D. V., L. L. Duda, P. R. B. Guimarães, and J. S. C. Fernandes. 2001. Análise de modelos lineares mistos via inferência Bayesiana. Revista de Matemática e Estatística 19:41-70.

Rosati, A., and L. D. Van Vleck. 2002. Estimation of genetic parameters for milk, fat, protein and mozzarella cheese production in Italian river buffalo population. Livest. Prod. Sci. 74:185-190.

Rupp, R., and D. Boichard. 1999. Genetic parameters for clinical mastitis, somatic cell score, udder type traits and milk ease in first lactation Holsteins. J. Dairy Sci. 82:2198-2204. 
Seno, L. O., V. L. Cardoso, and H. Tonhati. 2007. Economic values for milk production traits of dairy buffaloes in São Paulo State. Braz. J. Anim. Sci. 36:2016-2022.

Tonhati, H., P. S. Baruselli, J. F. S. Oliveira, B. F. Vasconcellos, and L. M. Toledo. 1996. Calving season, peak of lactation and milk production of the buffalo in Ribeira Valley, São Paulo State Brazil. Rev. Bubalus Bubalis, Salerno, Italia 3:63-67.

Tonhati, H., M. F. Cerón-Muñoz, J. A. Oliveira, L. El Faro, A. L. F. Lima, and L. G. Albuquerque. 2008. Test-day milk yield as a selection criterion for dairy buffaloes (Bubalus bubalis Artiodactyla, Bovidae). Genet. Mol. Biol. 31:674-679.

Tonhati, H., M. F. C. Muñoz, J. A. Oliveira, J. M. C. Duarte, T. P. Furtado, and S. P. Tseimazides. 2000. Genetic parameters of milk production, fat and protein contents in buffalo milk. Braz. J. Anim. Sci. 29:2051-2056.

Van Kaam, J. B. C. H. M. 1997. Gibanal: Analyzing program for Markov Chain Monte Carlo sequences, version 2.4. Dept. Anim. Sci., Wageningen Agric. Univ., Wageningen, the Netherlands.

Weller, J. I., A. Saran, and Y. Zeliger. 1992. Genetic and environmental relationships among somatic cell count, bacterial infection, and clinical mastitis. J. Dairy Sci. 75:2532-2540.

Welper, R. D., and A. E. Freeman. 1992. Genetic parameters for yield traits of Holstein including lactose and somatic cell score. J. Dairy Sci. $75: 1342-1348$ 